\title{
Development of an NCAM motorized GRAIN GRUEL (Soy Bean) sieving machine
}

\author{
Ridwan Olajide Jimoh, Funke Bosede Olotu, Sylvester Chukwujekwu Obiakor *, Kingsley Chibuzor Eneh, \\ Ridwan Adeniyi Alade and Olaoluwa Boladele Asamo.
} Processing and Storage Engineering Department, National Center for Agricultural Mechanization, Ilorin, Kwara State,
Nigeria.

Global Journal of Engineering and Technology Advances, 2021, 09(02), 065-074

Publication history: Received on 05 October 2021; revised on 16 November 2021; accepted on 18 November 2021

Article DOI: https://doi.org/10.30574/gjeta.2021.9.2.0147

\begin{abstract}
A survey carried out on conventional or traditional method of sieving wet grains showed that the method consumes time, energy, has low output and efficiency and is also hazardous to health due to low level of hygiene involved. A motorized grain gruel machine was developed at the National Centre for Agricultural Mechanization (NCAM), Ilorin Nigeria. The machine consists of four major units which are hopper, seiver, separator and the discharge unit. The machine's performance was evaluated at different water volumes (16.5, 18.5 and 20.5 liters) and at three different operating speeds namely $65.3 \mathrm{rpm}, 115.0 \mathrm{rpm}$ and $126.0 \mathrm{rpm}$. The parameters evaluated are; sieving efficiency, through put and output capacity. The data were analyzed using the New Duncan multiple range test (Post Hoc Test) method and linear regression model was used to establish the relationship between the independent variables with the dependent variable, which was optimized using pulp in python version 2.9 frame work. Results show that the machine performed higher at 20.5 litres and 126 rpm to a maximum sieving efficiency of $85.08 \%$ and $86.48 \%$ respectively, but was optimized to the range of $88.35-92.5 \%$ in sieving efficiency and $19.42-23.42 \mathrm{~kg} / \mathrm{hr}$ in output capacity. Also the analysis showed that water volume used had more significant effect on the efficiency and other variables such as the throughput and the output capacity respectively, than the operation speed. It was concluded from the results that the machine saved time and energy, reduced material wastage and hazards and therefore is more efficient than the conventional method. It is recommended that further evaluations should be carried out on the machine using a wider variety and species of grains samples.
\end{abstract}

Keywords: Development; Performance; sieving machine; Conventional method; Efficiency

\section{Introduction}

Grains gruel are legumes and cereals crops family, which are vital source vitamins, minerals, protein, carbohydrates, fats, oils, and protein. Grains products include soya milk, and maize pap and kunu products among others [1,2].

Soya bean which is the most economically and nutritionally significant among the lots and its popularly consumed as a bean has several uses, which includes soy milk, soya cheese (Beske), soy sauce, soy oil etc. It is a highly refreshing milk drink which is rich in nutrients, vitamins and minerals that help in optimal bone health, improved blood cholesterol, protection against cardiovascular diseases, soybean a suppressant for prostate and breast cancer reduces blood pressure and body weight regulation which makes it one of the natural beverage consumed in Nigeria [3, 4].

The final taste and natural flavor of the soy milk is dependent on the processing method used in the extraction of the milk. When processing the soya milk, asides the strenuous process taken to produce the milk and The processing operations involved in the production of soya milk include; Cleaning, steeping, wet milling, wet sieving, mixing, cooking

\footnotetext{
${ }^{*}$ Corresponding author: Sylvester Chukwujekwu Obiakor

Processing and Storage Engineering Department, National Center for Agricultural Mechanization, Ilorin, Kwara State, Nigeria. 
and filtering. The milling, mixing and separation of the soy milk from the slurry influence the final output and quality of the product $[5,6]$.

Fayose [6], Developed a Multi Purpose Wet Food Sieving Machine. The machine consists of a hopper, a mixing compartment, a sieving compartment operated by a crank and spring arrangement, collecting trays and outlets. The volumetric flow rate and the capacity of the machine were $0.0206 \mathrm{~m}^{3} / \mathrm{h}$ and $22.45 \mathrm{~kg} / \mathrm{h}$ respectively. The test concentration was conducted at three levels $12.2 \%, 14.44 \%$ and $22.77 \%$. The study showed that the machine performance coefficients and sieving capacity increased with decreasing concentration. Also, highest performance coefficients of $98 \%$ was obtained for sieving of maize while sieving capacity of $16.90 \mathrm{~g} / \mathrm{sm}^{2}$ was obtained when the machine was used to sieve cassava.

Ibrahim and Gbabo [7], developed a batched grain beverages processing machine capable of integrating and blending of soaked grains, mixing the slurry and extracting the aqueous liquid together. The results of testing of the machine using soya beans revealed that highest blending efficiency of $81.11 \%$ from combination of blade with contact area of $1.32 \times 10^{-3} \mathrm{~m}^{2}$, speed of blending of $1100 \mathrm{rpm}$ and blending time $540 \mathrm{sec}$, while the lower value of blending efficiency of $52.85 \%$ was obtained from combination of blade with contact area $6.8 \times 10^{-4} \mathrm{~m}^{2}$, speed of blending of $1000 \mathrm{rpm}$ and blending time $420 \mathrm{sec}$. The results of analysis of variance ANOVA also revealed that all the experiment factors have positive significant effects $(\mathrm{p} \leq 0.05)$ on the blending efficiency.

However, there is a dearth of literatures on modern efficient methods of processing and preservation of soya milk especially in the separation of milk from slurry residue.Hence, the need to develop soya milk production and separating machine. The sieving machine still has a lot to be desired in terms of efficiency and efficacy of the product. In addition, as reported by Faluyi et al [8], the hygiene of the product would be assured as there would be no physical contact between the operator and the product during operation so as to avoid contamination. Moreover, Sieving of wet products is often arduous, cumbersome and time consuming, as separating of the fine and coarse particle in water is an indispensable process as the grain biopolymers are extracted and the presence of water aids the separation as the soluble contents become dense and are suspended in water [6].

The objective of this study is to developed a modified grain gruel motorized sieving machine which will include a filter in order to reduce stress, by which the operator undertake when extracting milk from the wet grain gruel, having an enclosed sieving mechanism limiting human and atmospheric contamination, using low cost and available material and still having high sieving capacity and efficiency rate for small and medium scale processing of wet agricultural crops.

\section{Material and methods}

The major components of the equipment's are Sieving screen, Hopper, bearing, shaft, frame, pulley belt, filtering chamber, spring, and a prime mover.

\subsection{Design consideration}

In the design of the NCAM motorized grain gruel sieving machine following were taken into consideration:-

- Availability of construction materials: materials of adequate strength and durability were used for the fabrication, which were sourced locally.

- Cost: low cost materials that give adequate strength and stability were used for the fabrication.

- Physical and mechanical properties of the said grain: relevant geometric mean diameter of the grain was considered for the design of the machine.

- Basic considerations were given to the design of the size, speed and capacity of the machine.

\subsection{Description and Operation of the Developed NCAM Motorized Grain Gruel Sieving Machine}

The machine has a mainframe which holds other components of the machine in a rigid position while a reciprocating mechanism sieves the milk from the slurry. It has an overall dimension of $600 \mathrm{~mm} \times 600 \mathrm{~mm} \times 996.5 \mathrm{~mm}$. The seiver is a detachable component which is made up of a food grade stainless steel sieving screen, attached to a square mild steel frame which serves as the hopper. The sieving tray is fixed inside a frame made from $45 \mathrm{mx} 45 \mathrm{~mm}$ mild steel that holds it in place. This sieving frame has loaded springs attached to it, which sits on ball bearings that enhances easy movement of the sieving frame. The machine has a chute of dimension $590 \mathrm{~mm} \times 190 \mathrm{~mm}$ wide through which the sieving milk is collected. The machine is powered by a prime mover, while the sieving chamber of the machine was designed to be rectangular in shape with a dimension of $500 \mathrm{~mm} \times 450 \mathrm{~mm} \times 400 \mathrm{~mm}$. 
The stainless sieving screen was designed to be replaceable so as to allow sieves of different screen sizes to be interchanged so as to fit the consumer/customer's needs.

\subsection{Design calculations}

All the various parts and components of the motorized sieving machine were designed, using various appropriate equations..

\subsubsection{Hopper}

The volumetric capacity of the hopper was calculated using

$\mathrm{V}\left(\mathrm{m}^{3}\right)=\frac{\mathrm{M}}{\rho}$

Where,

$\mathrm{M}$ is the mass of cowpea in $(\mathrm{kg})$ and $\rho$ the bulk density of cowpea in $\left(\mathrm{kg} / \mathrm{m}^{3}\right)$

Therefore the area and the volume of the rectangular shaped hoper were calculated using the following equations bellow

The Area of the hopper $(\mathrm{A})=L \times B$

Volume of the hoper $(\mathrm{V})=L \times B \times H$

Where $\mathrm{L}$ is the length measured in meters $(\mathrm{m}), \mathrm{B}$ is the breath measured in meters $(\mathrm{m})$,

and $\mathrm{H}$ is the height of the hopper measured in meters(m).

\subsubsection{Pulley design}

The diameter of the pulley of the shaft was calculated to be $320 \mathrm{~mm}$ using the expression given by Khurmi and Gupta (2005)

$N_{1} D_{1}=N_{2} D_{2}$

\subsubsection{Belt design}

The belt speed, v (m/s) and its total belt length, (m), were calculated using the expression given by Khurmi and Gupta (2005), respectively

$\mathrm{V}=\frac{\pi N D}{60}$

Where,

$\mathrm{V}=$ Velocity of the belt, $\mathrm{N}=$ Revolution of the motor, $\mathrm{D}=$ Diameter of the motor pulley

$L=\frac{\pi}{2}\left(D_{1}+D_{2}\right)+2 C+\frac{\left(D_{1}+D_{2}\right)^{2}}{4 C}$

$C=\frac{D_{1}+D_{2}}{2}+0.05$

Where, 
$\mathrm{L}=$ Length of Belt, $\mathrm{D}_{1}=$ Driver Pulley diameter, $\mathrm{D}_{2}=$ Driven Pulley Diameter, $\mathrm{c}=$ Pulley Centre Distance.

\subsubsection{Torque transmitted by the shaft}

The torque transmitted by each shaft was calculated using the equation below

$$
T=\frac{P 60}{2 \pi N}
$$

\subsubsection{Shaft design}

The combine twisting moments and bending moments were used to determine the shaft diameter by using the formula given by Khurmi and Gupta (2005)

$T_{e}=\left(\left(K_{B} \times M\right)^{2}+\left(K_{T} \times T\right)^{2}\right)^{0.5}=\pi \times S_{S} \times \frac{d^{3}}{16}$

Where,

$\mathrm{T}_{\mathrm{e}}=$ equivalent twisting moment $(\mathrm{Nm}) \quad, \mathrm{M}=$ resultant bending moment $(\mathrm{Nm})$

$\mathrm{T}=$ Torque transmitted by the gear shaft $(\mathrm{Nm}), \mathrm{s}=$ Allowable shear stress with keyway $=45 \mathrm{~N} / \mathrm{mm}^{2}$ as given by Khurmi and Gupta, (2005)

$\mathrm{d}=$ diameter of the shaft in $\mathrm{mm}$

$\mathrm{K}_{\mathrm{B}}=$ combined shock and fatigue factor applied to bending moment $=2.0$ for minor shock

$\mathrm{K}_{\mathrm{T}}=$ combined shock and fatigue factor applied to torsional moment $=1.5$ for minor shock .

\subsection{Design Drawings}

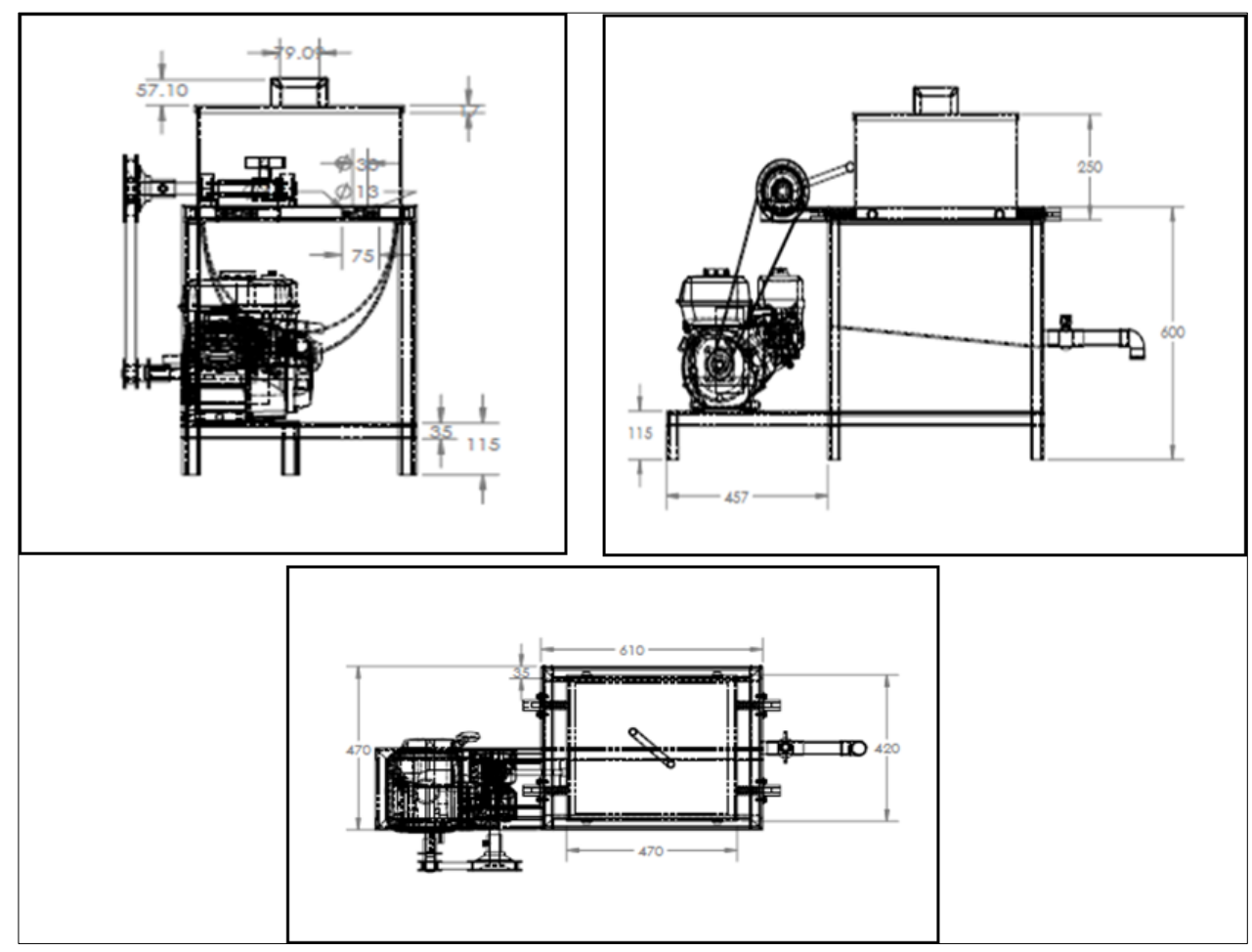

Figure 1 Orthographic view of the machine. 


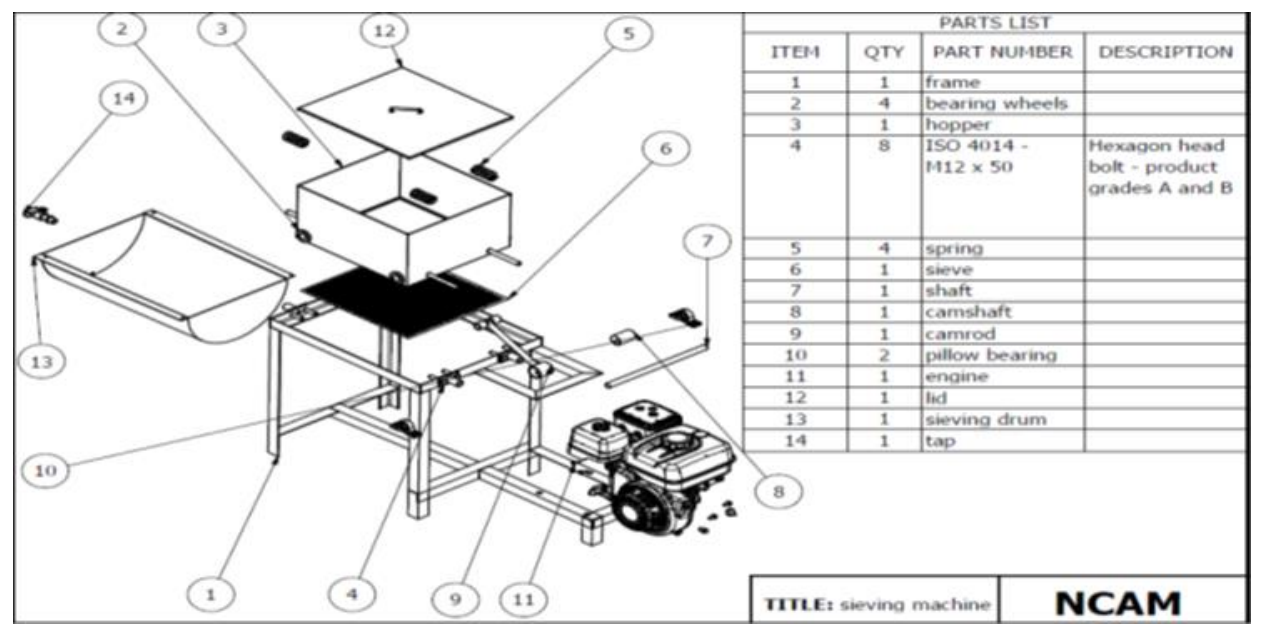

Figure 2 Exploded view of the developed NCAM sieving machine

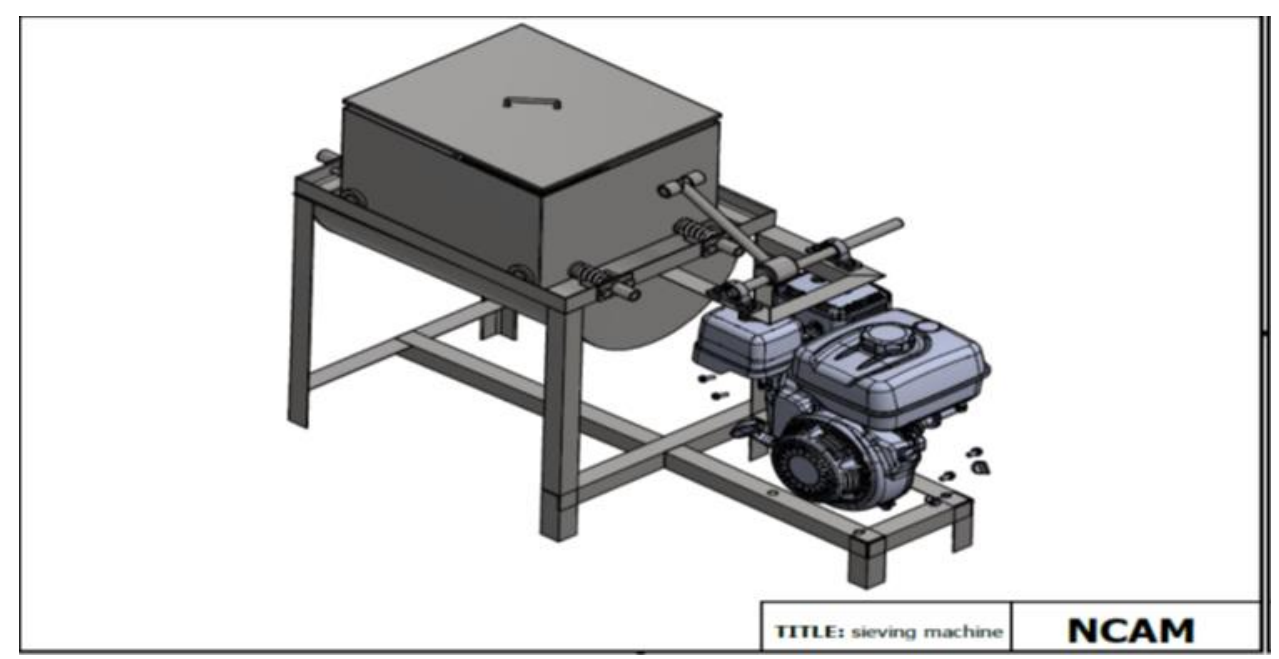

Figure 3 Isometric view of the machine

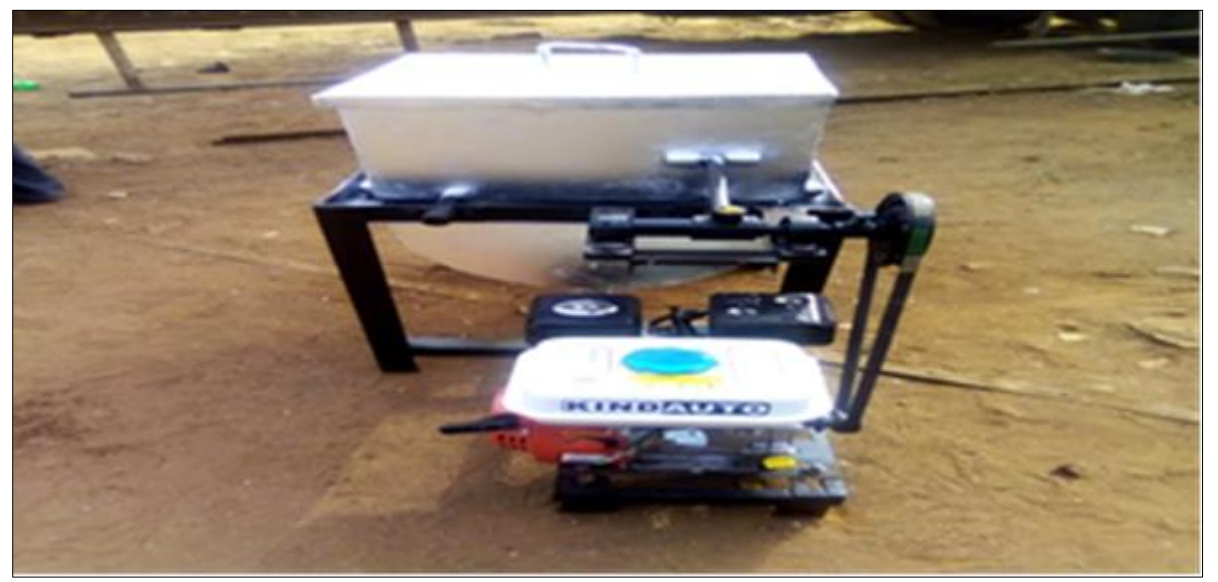

Figure 4 The Developed NCAM Motorized grain gruel Sieving Machine 


\subsection{Fabrication techniques}

\subsubsection{Fabrication Process}

The fabrication process of the machine was done at NCAM Engineering services workshop. The basic manufacturing processes include cutting, bending, and primary shaping and joining.

\section{Hopper}

The hopper is rectangular in shape, based with a portion attached to the seiver it is made of mild steel of $1.5 \mathrm{~mm}$ thickness. The fabrication was done by marking out the measurement on the plate, cutting it into shapes, welding and giving it a finishing touch by grinding.

Frame

The frame which is a rigid rectangular support, gives support to the whole system. it has an overall dimension of $600 \mathrm{~mm} \times 600 \mathrm{~mm} \times 996.5 \mathrm{~mm}$ angle iron and the engine seat has a dimension of $280 \mathrm{~mm} \times 515 \mathrm{~mm}$. The fabrication procedure was done by marking and cutting out the angle iron into its different length using power hack saw. The rectangular angle iron frame was firmly joined together by wielding.

Sieving chamber

The sieving chamber of the machine was cut and welded to a desired /designed dimensions of $500 \mathrm{~mm} \times 450 \mathrm{~mm} \mathrm{x}$ $400 \mathrm{~mm}$, while the discharge outlet in the halve is situated at the opposite end of the inlet end is $66 \mathrm{~mm} \times 40 \mathrm{~mm}$. It was fabricated by marking out $90 \mathrm{~mm}$ diameter pipe into the desired length, then cutting off the excess length to the required shape .The finishing was done by grinding.

\subsection{Performance Evaluation of the motorized Sieving Machine}

\subsubsection{Test Methodology}

The NCAM motorized grain gruel sieving machine, after Fabrication of the machine, preliminary tests was carried out using corn mill and milled soy beans. The time taken to fully sieve and drain out was recorded with a stop watch, while the weight of the residue was measured and also recorded in 3 replicates.

The corn and Soya beans used was gotten from the local market in Ilorin, Kwara state and were then sorted, cleaned, weighed and milled to ensure only healthy grains was used to evaluate the machine parameters.

\subsubsection{Test Parameters}

Sieving Efficiency (\%): this determines how efficiently the sieving machine carries out the sifting of the wet grain product. it is expressed as

$$
S_{e}=\frac{w_{3}}{w_{3}+w_{4}} \times 100
$$

Where $w_{4}=$ weight retained in the sieve expressed in $\mathrm{kg}$, and $w_{3}=$ weight of sieved wet grains expressed in $\mathrm{kg}$.

Sieved Mash Recovery (\%): this indicate the percentage of grain mash that is recovered after the sieving operation. it is expressed as below

$$
S_{r}=\frac{w_{3}+w_{5}}{w_{1}} \times 100
$$

Where $w_{3}=$ weight of sieved product expressed in $\mathrm{kg}, w_{5}=$ weight of mash expressed in $\mathrm{kg}$, and $w_{1}=$ weight at the outlet expressed in $\mathrm{kg}$.

Output Capacity $(\mathrm{Kg} / \mathrm{hr})$ : it determines the quantity of sieved grains product that is discharged from the outlet per unit time. it is expressed as 
$O_{c}=\frac{w_{3}}{t_{1}}$

Where $w_{3}=$ weight of sieved product expressed in $\mathrm{kg}$, and $t_{1}=$ time taken for the given operation

Throughput capacity $(\mathrm{Kg} / \mathrm{hr})$ : this is the quantity of unsieved product fed into the sieving machine per unit time. it is expressed below as

$I_{c}=\frac{w_{1}}{t_{1}}$

Where $w_{1}=$ weight at the mash outlet expressed in $\mathrm{kg}$, and $t_{1}=$ time taken

\subsection{Statistical Analysis}

New Duncan multiple range test (Post Hoc Test) method was used to determine the effect of the operational speed (65.3,115.0,and126.0rpm respectively) and the volume of water used on all parameters during the sieving operation. While the linear regression model was used to establish the relationship between the independent variables (operational speed, and volume of water used) with the dependent variable (sieving efficiency and output capacity).Pulp optimization model in python was used to optimize the process. The test was subjected into triplicates during data collection.

\section{Results and discussion}

Table 1 shows that the volume/quantity of water used during the sieving operation on Corn Mill had a significant effect on the through put, output and the sieving efficiency of the machine. Increasing the volume of waters from $16.5,18.5$ and 20.5litres made the through put of the machine to increase from 13.57 to $19.57 \mathrm{~kg} / \mathrm{hr}$, output capacity from 12.37 to $18.95 \mathrm{~kg} / \mathrm{hr}$ and the sieving efficiency from 78.49 to $85.08 \%$ respectively.

The significant difference observed at the through put was even, but at the output capacity it was discovered that the difference was more at 16.26 (18.5litres), while it was also observed that was a shoot-up in the efficiency difference at 20.5 liters $(85.08 \%)$ compare to the others. This is possibly due to the continuous increase in water volume during the operation aided the adequate dissolution of the wet milled grains which made more of them to pass through the sieving pores of the machine..

Table 1 Effect of Quantity Water for Sieving on Grain Gruel Sieving Machine Using Corn Mill

\begin{tabular}{|c|c|c|c|c|}
\hline S/No & $\begin{array}{c}\text { Quantity of Water } \\
\text { (Litre) }\end{array}$ & $\begin{array}{c}\text { Throughput } \\
\text { Capacity (kg/hr) }\end{array}$ & $\begin{array}{c}\text { Output Capacity } \\
\text { (kg/hr) }\end{array}$ & $\begin{array}{c}\text { Sieving } \\
\text { Efficiency (\%) }\end{array}$ \\
\hline 1 & 16.5 & $13.57_{\mathrm{a}}$ & $12.37_{\mathrm{a}}$ & $78.49_{\mathrm{a}}$ \\
\hline 2 & 18.5 & $16.57_{\mathrm{b}}$ & $16.26_{\mathrm{b}}$ & $80.99_{\mathrm{b}}$ \\
\hline 3 & 20.5 & $19.57_{\mathrm{c}}$ & $18.95 \mathrm{c}$ & $85.08_{\mathrm{c}}$ \\
\hline Sig & 1.000 & & & \\
\hline
\end{tabular}

Table 2 shows that the operational machine speed used during the sieving operation on Corn Mill, had a significant effect on the through put, output and the sieving efficiency of the machine

Increasing the machine operational speed from 65.3, 115.0 and $126.0 \mathrm{rpm}$ had no significant difference on the through put of the machine which remains constant at $16.57 \mathrm{~kg} / \mathrm{hr}$, same as the output capacity which became significant at $126.0 \mathrm{rpm}$ given rise from 15.7 to $16.19 \mathrm{~kg} / \mathrm{hr}$, there was a significant difference observed at the sieving efficiency from 77.28 to $86.48 \%$ respectively. 
The result explains that the change in speed had no effect on the through put capacity but made an impact on the output capacity when more speed of $126 \mathrm{rpm}$ was applied resulting to a higher sieving efficiency of $86.48 \%$.

Table 2 Effect of Operating Speed on the Grain Gruel Sieving Machine using Corn Mill

\begin{tabular}{|c|c|c|c|c|}
\hline S/No & $\begin{array}{c}\text { Operating } \\
\text { Speed (rpm) }\end{array}$ & $\begin{array}{c}\text { Throughput } \\
\text { Capacity }(\mathbf{k g} / \mathbf{h r})\end{array}$ & $\begin{array}{c}\text { Output Capacity } \\
\mathbf{( k g / h r )}\end{array}$ & $\begin{array}{c}\text { Sieving } \\
\text { Efficiency (\%) }\end{array}$ \\
\hline 1 & 65.3 & $16.57_{\mathrm{a}}$ & $15.64 \mathrm{a}$ & $77.28_{\mathrm{a}}$ \\
\hline 2 & 115.0 & $16.57_{\mathrm{a}}$ & $15.74 \mathrm{a}$ & $80.80_{\mathrm{b}}$ \\
\hline 3 & 126.0 & $16.57_{\mathrm{a}}$ & $16.19 \mathrm{c}$ & $86.48 \mathrm{c}$ \\
\hline Sig & 1.000 & & & \\
\hline
\end{tabular}

Table 3 shows that the volume/quantity of water used during the sieving operation on Soybean Mill, had a significant effect on the through put, output and the sieving efficiency of the machine

Increasing the volume of waters used from 16.5, 18.5 and 20.5litres made the through put of the machine to increase from 19.34 to $23.30 \mathrm{~kg} / \mathrm{hr}, 18.49$ to $22.30 \mathrm{~kg} / \mathrm{hr}$ and the sieving efficiency from 78.49 to $85.07 \%$ respectively.

The significant difference observed at the through put was even, but at the output capacity it was discovered that the difference was also even, while it was also observed that was a shoot-up in the efficiency difference at 20.5 liters $(85.07 \%)$ compare to the others. This possibility buttresses the facts that more water volume introduction during the operation supports the total dissolving of the products ,thereby easing the sieving enhancing operation.

Table 3 Effect of Quantity Water for Sieving on Grain Gruel Sieving Machine Using Soybean Mill

\begin{tabular}{|c|c|c|c|c|}
\hline S/No & $\begin{array}{c}\text { Quantity of } \\
\text { Water (Litre) }\end{array}$ & $\begin{array}{c}\text { Throughput } \\
\text { Capacity (kg/hr) }\end{array}$ & $\begin{array}{c}\text { Output Capacity } \\
\text { (kg/hr) }\end{array}$ & $\begin{array}{c}\text { Sieving } \\
\text { Efficiency (\%) }\end{array}$ \\
\hline 1 & 16.5 & $19.34_{\mathrm{a}}$ & $18.49_{\mathrm{a}}$ & $78.49_{\mathrm{a}}$ \\
\hline 2 & 18.5 & $21.20_{\mathrm{b}}$ & $20.19_{\mathrm{b}}$ & $80.99_{\mathrm{b}}$ \\
\hline 3 & 20.5 & $23.30_{\mathrm{c}}$ & $22.30_{\mathrm{c}}$ & $85.07_{\mathrm{c}}$ \\
\hline Sig & 1.000 & & & \\
\hline
\end{tabular}

Table 4 shows that the operational machine speed used during the sieving operation on Soybean Mill, had a significant effect on the through put, output and the sieving efficiency of the machine.

Increasing the machine operational speed from 65.3, 115.0 and $126.0 \mathrm{rpm}$ made the through put of the machine to increase from 19.29 to $22.61 \mathrm{~kg} / \mathrm{hr}$, the output capacity from 18.39 to $21.46 \mathrm{~kg} / \mathrm{hr}$ and the sieving efficiency from 78.49 to $85.07 \%$ respectively.

No significant difference on the through put of the machine was observed, which remains constant at $16.57 \mathrm{~kg} / \mathrm{hr}$, same as the output capacity which became significant at $126.0 \mathrm{rpm}$ given rise to increase from 15.7 to $16.19 \mathrm{~kg} / \mathrm{hr}$, there was a significant difference observed at the sieving efficiency from 77.28 to $86.48 \%$ respectively.

The result explains that the change in speed on this specific operation had made a significant effect on all the variables, though minimal but was more pronounced on the efficiency especially when 126rpm operational speed was applied resulting to a higher sieving efficiency of $86.48 \%$.

A Linear regression model was used to establish the relationship between the independent variables (speed and volume of water used) with the dependent variable (sieving efficiency and output capacity ) for the soy bean operation in equation 13 (sieving efficiency) and equation 14 (throughput), optimization of the model using pulp model frame work 
in python shows that the highest sieving efficiency and output capacity achievable using soy bean in operation is $92.5 \%$ and $23.42 \mathrm{~kg} / \mathrm{hr}$ respectively with an operational speed of $126 \mathrm{rpm}$ and water volume of 20.5liters.

Table 4 Effect of Operating Speed on the Grain Gruel Sieving Machine using Soybean Mill

\begin{tabular}{|c|c|c|c|c|}
\hline S/No & $\begin{array}{c}\text { Operating Speed } \\
\text { (rpm) }\end{array}$ & $\begin{array}{c}\text { Throughput } \\
\text { Capacity (kg/hr) }\end{array}$ & $\begin{array}{c}\text { Output Capacity } \\
\text { (kg/hr) }\end{array}$ & $\begin{array}{c}\text { Sieving Efficiency } \\
\text { (\%) }\end{array}$ \\
\hline 1 & 65.3 & $19.29_{\mathrm{a}}$ & $18.39_{\mathrm{a}}$ & $77.28_{\mathrm{a}}$ \\
\hline 2 & 115.0 & $21.95_{\mathrm{b}}$ & $21.13_{\mathrm{b}}$ & $80.80_{\mathrm{b}}$ \\
\hline 3 & 126.0 & $22.61_{\mathrm{c}}$ & $21.46_{\mathrm{c}}$ & $86.48_{\mathrm{c}}$ \\
\hline Sig & 1.000 & & & \\
\hline
\end{tabular}

The sensitivity of the system suggests increasing the optimum speed by $0.09 \mathrm{rpm}$ and the volume of water used by 1.23 $\mathrm{kg} / \mathrm{hr}$ will improve the optimum sieving efficiency of the machine during soy bean operation, also suggesting that increasing the optimum speed by $0.05 \mathrm{rpm}$ and the water volume by $0.95 \mathrm{~kg} / \mathrm{hr}$ will increase the output capacity of the machine during the soy bean operation.

The linear regression equation for the sieving efficiencyand outputcapacity isgiven in Equation (13 and 14), and it indicates the importance of increased in the quantity of water needed for an effective and efficient sieving process.

$\mathrm{S}=0.09 \mathrm{~V}_{\mathrm{o}}+1.23 \mathrm{~W}_{\mathrm{u}}+59.27$

$\mathrm{O}_{\mathrm{p}}=0.05 \mathrm{~V}_{\mathrm{o}}+0.95 \mathrm{Wu}-2.61$

Linear regression model was used to establish the relationship between the independent variables (speed and volume of water used) with the dependent variable (sieving efficiencies and output capacity) for the corn operation in equation 15 (sieving efficiency) and equation 16 (output capacity)), optimization of the model using pulp model frame work in python shows that the highest sieving efficiency and output capacity achievable using corn in operation is $88.35 \%$ and $19.42 \mathrm{~kg} / \mathrm{hr}$ respectively with an operational speed of $126 \mathrm{rpm}$ and water volume of 20.5 liters.

The sensitivity of the system suggests increasing the optimum speed by $0.13 \mathrm{rpm}$ and the volume of water used by 1.65 $\mathrm{kg} / \mathrm{hr}$ will improve the optimum sieving efficiency of the machine during corn mill operation, also suggesting that increasing the optimum speed by $0.007 \mathrm{rpm}$ and the water volume by $1.65 \mathrm{~kg} / \mathrm{hr}$ will increase the output capacity of the machine during the soy bean operation.

The optimization equation for the sieving efficiency and outputcapacity isgiven in Equation (15 and 16), and it indicates the importance of increased quantity of water needed for an effective and efficient sieving process same as soy bean operation.

$\mathrm{S}=0.13 \mathrm{~V}_{\mathrm{o}}+1.65 \mathrm{~W}_{\mathrm{u}}+38.14$

$0 \mathrm{p}=0.007 \mathrm{~V}_{\mathrm{o}}+1.65 \mathrm{~W}_{\mathrm{u}}-2.61$

Where $\mathrm{S}$ is the sieving efficiency measured in $\%, \mathrm{O}_{\mathrm{p}}$ is the output capacity measured in $\mathrm{kg} / \mathrm{hr}, \mathrm{V}_{\mathrm{o}}$ is the machine operation speed in (RPM), and Wu is the water used during the sieving operation in (liters). 


\section{Conclusion}

The motorized grain gruel (soy bean) sieving machine was designed, fabricated and evaluated to ascertain its performance. The higher sieving efficiency was recorded using both speed and water volume as varying factors. The maximum sieving efficiencies achieved were $85.07 \%$ and $86.48 \%$, this values were achieved at the sieving machine operational speed of $126 \mathrm{rpm}$ and water volume of 20.5 litres.

A regression model was established for the processes and was optimized; the optimized results showed that the machine operation could achieve efficiency in the range of $88.35-92.5 \%$ and an output capacity of $19.42-23.42 \mathrm{~kg} / \mathrm{hr}$ respectively using optimum independent variables of speed 126rpm and water volume used of 20.5litres.

From the analysis it could be deducted that the quantity of water used during the sieving operation had more significant effect on the efficiency than the speed, though the speed had an effect, it was be minimal

The machine would therefore eliminate the constraints involved in the manual processing and reduced operational losses associated to grain gruel sieving operations as it's tends to provide an improved quality product.

\section{Recommendation}

Further evaluations should be carried out on the machine using a wider variety, weights and species of grains samples.

\section{Compliance with ethical standards}

\section{Acknowledgments}

We sincerely appreciate the effort of the Executive Director and the Management team of the National Centre for Agricultural Mechanization (NCAM) for providing the resources for this research. More also, we appreciate the research team for their commitment towards actualizing the research objectives.

\section{Disclosure of conflict of interest}

The authors declare there have no conflict of interest.

\section{References}

[1] Gbabo A, Gana MI,Dauda SM. Effect of blade types on the blending efficiency and milk consistency of a grains drink processing machine. Academic Research International. 2012; 2(3): 41-49.

[2] Adebayo-Tayo BC, Adegoke AA,Akinjogunla OJ. Microbial and physicochemical quality of powdered soymilk samples in Akwa Ibom, South Southern Nigeria. African Journal of Biotechnology. 2009; 8(13): 3066-3071.

[3] Amusa NA, Ashaye OA, Aiyegbayo AA, Oladapo MO, Oni MO,Ajolabi OO. Microbiological and nutritional quality of hawked sorrel drinks (soborodo) (the Nigerian locally brewed soft drinks) widely consumed and notable drinks in Nigeria. Journal of Food Agriculture and Environment. 2005; 3(3-4): 47-50.

[4] Gana IM,Gbabo A. Design of mini plant for soya milk production and pasteurization. Agricultural Engineering International: CIGR Journal. 2017; 19(4): 45-53.

[5] Gana IM,Gbabo A. Design, fabrication and testing of batched grain beverages processing machine. M0J Food Processing \& Technology. 2018; 6(1):139-149.

[6] Fayose FT. The Development of a Multi Purpose Wet Food Sieving Machine. Agricultural Engineering International: CIGR Journal, X. 2008; 1-9.

[7] Ibrahim MG, Gbagbo,A. Design, Fabrication and Testing Of Batched Grains Beverages Processing Machine.MOJ food processing and technology. 2018; vol.6, issue1.

[8] Faluyi O, Opadoja D, Adedoyin RA. Design and Fabrication of soya milk extracting machine. International Journal of engineering and technical research.2019: volume 8.issue 9. 